\title{
TUBEROUS SKLEROSIS PADA ANAK
}

\author{
Sandra Ayamiseba \\ Pieter L. Suling \\ Bagian Ilmu Kesehatan Kulit dan Kelamin \\ Fakultas Kedokteran Universitas Sam Ratulangi Manado \\ Email: ayamiseba.sandra@gmail.com
}

\begin{abstract}
Tuberous sclerosis (TS) is an autosomal dominant disease associated with mutation of one of two different genes, TSC1 or TSC2. The typical clinical picture of TS cases is skin lesions, mental retardation, and epilepsy. According to the consensus of TS alliance, the US National Tuberous Sclerosis Association, in July 1998, the diagnostic criteria of TS are based on major and minor symptoms: two major symptoms, or one major and two minor symptoms. The management of the skin disorders such as angiofibroma with a cosmetic purpose can be done by using electrocauterization, dermabrasion, and excision. The prognosis depends on the systemic involvement. We reported a case of a male, aged 7 years, with 2 major symptoms of TS: facial angiofibroma that spreaded to his neck and back, and hypomelanotic macula on his back. The histopathological examination showed subepithelial keratosis associated with fibrocollagen tissue and teleangiectasis in the stroma, atrophy of sebacceous glands, without any malignancy. Conclusion: In this case, the diagnosis of tuberous sclerosis was based on anamnesis, clinical picture (two major symptoms), and histopathological examination. Electrocauterization could not be performed because the patient was incooperative. The prognosis was quo ad vitam, quo ad functionam, quo ad sanationam: dubia.
\end{abstract}

Keywords: tuberous sclerosis, multiple hyperpigmented nodule

\begin{abstract}
Abstrak: Tuberous sklerosis (TS) merupakan suatu penyakit autosomal dominan yang dihubungkan dengan mutasi satu dari dua gen yang berbeda, yaitu TSC1 atau TSC2. Gambaran klinis yang khas pada kasus ini ialah lesi kulit, retardasi mental, dan epilepsi. Berdasarkan konsensus aliansi US National Tuberous Sclerosis Association pada Juli 1998 dirumuskan kriteria diagnostik berdasarkan adanya gejala mayor dan minor, yaitu dua gejala mayor; atau satu gejala mayor dan dua gejala minor. Prinsip pengobatan untuk kelainan kulit berupa angiofibroma dengan tujuan kosmetik yaitu dengan elektrokauter, dermabrasi, dan eksisi. Prognosis tergantung pada keterlibatan sistemik. Pada kasus ini ditemukan 2 gejala mayor yaitu angiofibroma pada wajah yang menyebar ke leher dan punggung serta makula hipomelanotik pada punggung. Pemeriksaan histopatologik jaringan menunjukkan hiperkeratosis subepitelial di lapisan epidermis. Tampak stroma jaringan ikat fibrokolagen dengan pelebaran pembuluh darah kapiler, kelenjar sebaseus atrofi, dan tidak didapatkan tanda-tanda keganasan. Simpulan: Pada kasus ini, diagnosis TS ditegakkan berdasarkan anamnesis, gambaran klinis (2 gejala mayor), dan pemeriksaan histopatologik. Penatalaksanaan dengan elektrokauter tidak dapat dilakukan karena pasien tidak kooperatif. Prognosis tergantung gejala klinis, quo ad vitam, quo ad functionam, quo ad sanationam: dubia.
\end{abstract}

Kata kunci: tuberous sklerosis, nodul hiperpigmentasi multipel

Tuberous sklerosis (TS) merupakan dihubungkan dengan mutasi satu dari dua penyakit autosomal dominan yang gen yang berbeda, TSC1 (tuberous 
sklerosis kompleks 1) atau TSC2 (tuberous sklerosis kompleks 2). ${ }^{1}$ Penyakit ini juga dikenal sebagai Bourneville's dan epiloia (epi $=$ epilepsi, loi $=$ low of intelegence, $\mathrm{a}=$ adenoma sebaseum). ${ }^{2}$ Epiloia merupakan trias klasik yang pertama kali diperkenalkan oleh Vogt pada tahun 1908. Lesi utama terdapat pada kulit, sistem saraf, dan ginjal. Manifestasi klinis yang paling umum dijumpai ialah makula hipopigmentasi (ash leaf), adenoma sebaseus, kejang, dan retardasi mental. ${ }^{1-3}$

Tuberous sklerosis jarang ditemukan dengan insidensi 1 dari 10.000 kelahiran. Frekuensi pada laki-laki dan perempuan sama pada berbagai ras dan etnik. ${ }^{4-6}$

Patogenesis penyakit ini disebabkan oleh mutasi gen TSC1 atau TSC2 yang merupakan gen supresor tumor. Gen tuberous sclerosis complex 1 berlokasi pada kromosom 9q34 diberi kode untuk protein hamartin sedangkan gen $\mathrm{TSC} 2$ berlokasi di kromosom 16p1 diberi kode untuk protein tuberin. ${ }^{1,5,7}$

Gambaran klinis yang khas pada penyakit ini berupa lesi pada kulit, retardasi mental serta epilepsi. ${ }^{1}$ Berdasarkan konsensus Aliansi Tuberous Sklerosis yang selanjutnya dikenal sebagai US National Tuberous Sclerosis Association pada Juli 1998 dirumuskan kriteria diagnostik TS berdasarkan gejala mayor dan minor. Untuk menegakkan diagnosis TS diperlukan dua gejala mayor; atau satu gejala mayor dan dua gejala minor. Gejala mayor berupa angiofibroma pada wajah atau plak pada dahi, fibroma ungual atau periungual non traumatik, makula hipomelanotik (3 atau lebih), Shagreen patch (nevus jaringan penyambung), nodul hamartoma multipel pada retina (multiple retinal nodular hamartomas), tuber kortikal, nodul subependimal, astrositoma sel raksasa subependimal (subependymal giant cell astrocytoma), rabdomioma kardiak tunggal atau multiple (single or multiple cardiac rhabdomyoma), limfangiomiomatosis (lymphangiomyomatosis), dan renal angiomiolipoma (renal angiomyolipoma). ${ }^{1}$ Gejala minor berupa celah pada email gigi yang multipel dan terdistribusi acak (multiple randomly distributed pits in dental enamel), polip rektal, kista pada tulang, fibroma gingival, hamartoma non renal, lesi kulit Confetti, dan kista multipel ginjal., ${ }^{4,8}$,

Prinsip pengobatan pada kelainan kulit berupa angiofibroma ialah memperbaiki secara kosmetik dengan elektrokauter, dermabrasi, atau eksisi bedah. ${ }^{1,6,9,10}$

Prognosis tergantung pada ada tidaknya keterlibatan sistemik. Individu dengan gejala ringan umumnya bertahan hidup lebih lama. Pada kasus berat sebanyak $30 \%$ meninggal sebelum usia 1 tahun dan sebanyak 50-70\% meninggal sebelum dewasa. ${ }^{1,6,9,10}$

\section{LAPORAN KASUS}

Seorang anak laki-laki berusia 7 tahun datang ke poliklinik kulit dan kelamin RSUP Prof. Dr. R. D. Kandou Manado dengan keluhan benjolan-benjolan kecil di wajah dan bercak-bercak putih di badan yang dialami sejak 4 tahun lalu.

Awalnya benjolan timbul di dekat hidung, yang makin bertambah banyak dan menyebar ke leher serta punggung. Benjolan kadang terasa gatal namun tidak nyeri dan tidak mudah berdarah. Bercakbercak putih muncul di bagian perut sejak 1 tahun lalu, tidak gatal, dan tidak mati rasa.

Pasien sudah pernah berobat ke dokter ahli penyakit kulit dan kelamin dan diberikan obat minum (pasien tidak tahu nama obatnya), namun saat itu benjolan hanya berkurang sedikit. Benjolan tersebut makin lama makin bertambah banyak.

Riwayat kejang disangkal. Riwayat penyakit yang sama di keluarga disangkal. Riwayat kelahiran pasien lahir secara normal di bidan dan tidak ada gangguan tumbuh kembang. Riwayat alergi makanan dan obat disangkal. Riwayat atopi (rinitis berulang dan asma) disangkal. Keluhan ini baru dialami pasien pertama kali.

Pada pemeriksaan fisik didapatkan papul-papul dan nodul multipel hiperpigmentasi pada daerah wajah dan leher. Makula hipopigmentasi yang berbatas jelas berukuran lentikuler hingga numuler 
didapatkan pada daerah punggung.

Hasil pemeriksaan laboratorium darah didapatkan kenaikan leukosit sebesar $11.000 / \mathrm{mm}^{3}$. Hasil pemeriksaan radiologik tulang panjang dan telapak tangan tidak ditemukan kelainan. Hasil pemeriksaan histopatologik ditemukan jaringan kulit dilapisi epidermis dengan hiperkeratosis subepitelial di lapisan epidermis. Tampak stroma jaringan ikat fibrokolagen dengan pelebaran pembuluh darah kapiler dan kelenjar sebaseus yang atrofi. Tidak didapatkan tanda-tanda keganasan.

Hasil konsultasi ke Bagian Psikiatri didapatkan IQ pasien 80 (di bawah rata-rata anak normal). Pasien sudah pernah berobat ke Poliklinik Penyakit Saraf dan Poliklinik Ilmu Kesehatan Mata tetapi tidak ditemukan kelainan.

Pasien didiagnosis dengan tuberous sklerosis dan direncanakan untuk dilakukan elektrokauterisasi pada lesi papul-papul di wajah dan leher namun pasien tidak kooperatif, sehingga tindakan tidak dapat dilakukan.
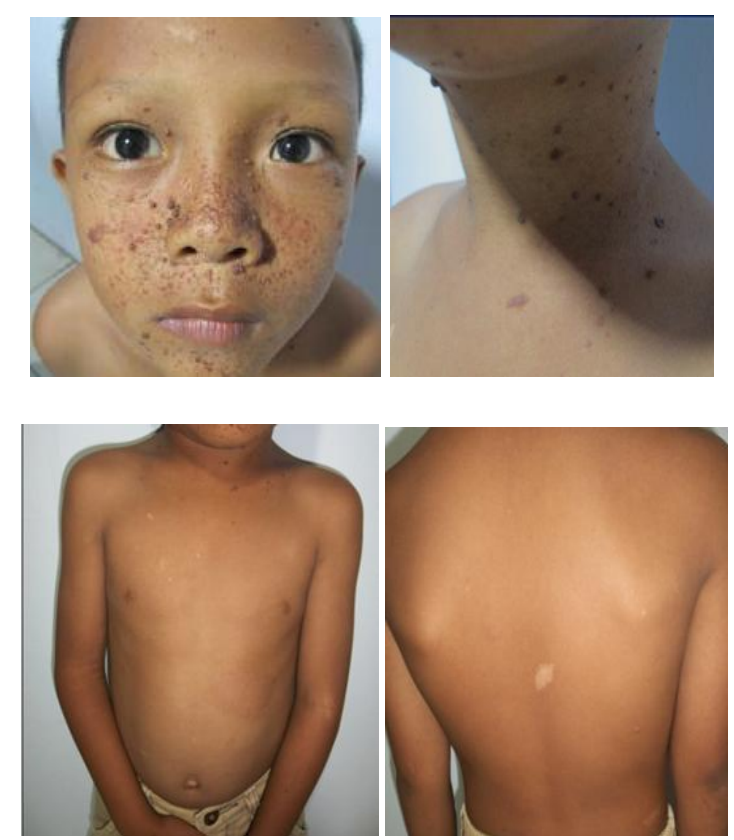

Gambar 1. Papul-papul dan nodul multipel hiper-pigmentasi pada daerah wajah dan leher. Makula hipopigmentasi yang berbatas jelas berukuran lentikuler hingga numuler didapatkan pada daerah punggung.
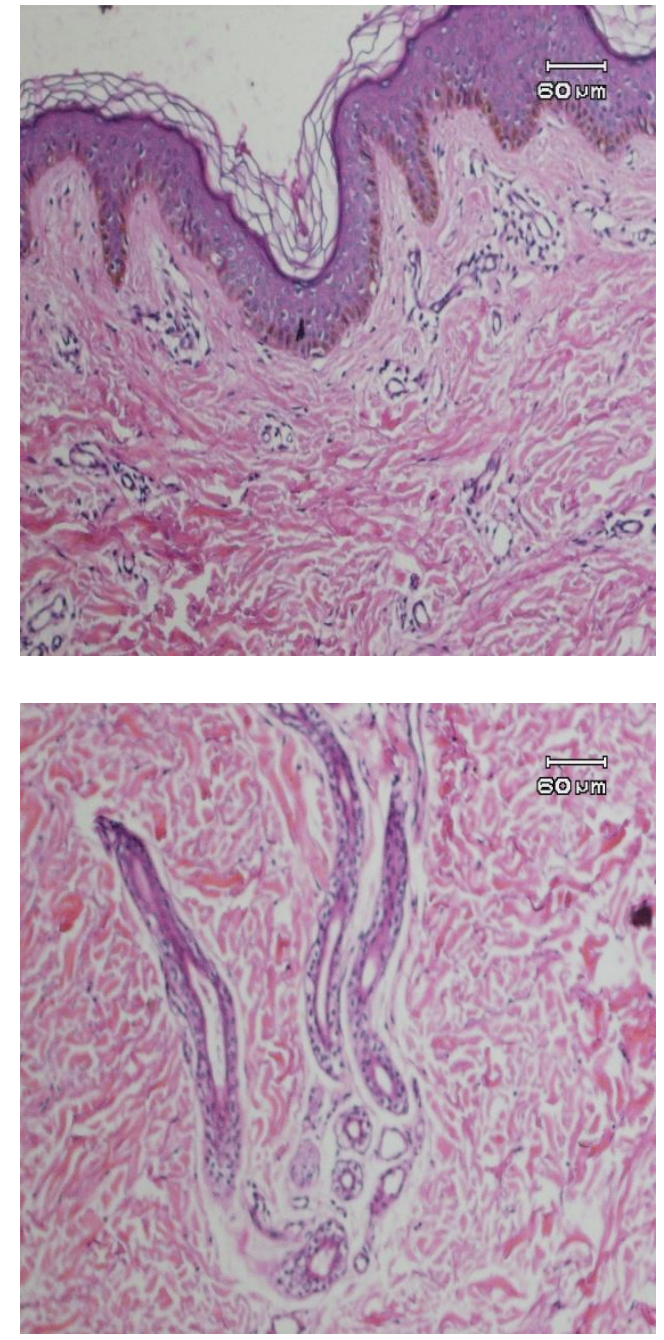

Gambar 2. Hasil pemeriksaan histopatologik jaringan pada makula hipopigmentasi. A, hiperkeratosis subepitelial di lapisan epidermis. Tampak stroma jaringan ikat fibrokolagen dengan pelebaran pembuluh darah kapiler dan B, kelenjar sebaseus yang atrofi. Tidak didapatkan tanda-tanda keganasan.

\section{BAHASAN}

Diagnosis tuberous sklerosis (TS) ditegakkan berdasarkan anamnesis, gejala klinis berupa dua gejala mayor atau satu gejala mayor ditambah dengan dua gejala minor dan didukung oleh hasil pemeriksaan histopatologik. Pada kasus ini, diagnosis TS ditegakkan berdasarkan anamnesis, gejala klinis yaitu adanya angiofibroma pada wajah atau plak pada dahi serta makula hipomelanotik (2 gejala mayor), dan pemeriksaan histopatologik. 
Pasien seorang anak laki-laki berusia 7 tahun dengan keluhan benjolan-benjolan kecil di wajah sejak 3 tahun lalu. Awalnya benjolan timbul di dekat hidung, yang makin lama makin bertambah banyak dan menyebar ke leher serta punggung. Benjolan-benjolan ini kadang terasa gatal, tidak mudah berdarah, tidak nyeri. Sekitar 1 tahun lalu, bercak putih timbul di bagian perut dan punggung yang makin bertambah banyak, tidak gatal, dan tidak ada keluhan mati rasa. Pasien sudah berobat ke dokter kulit pada saat pasien berusia 3 tahun diberi beberapa obat minum, tapi hanya berkurang sedikit, kemudian timbul lagi dan menjadi banyak hingga sekarang. Pasien sudah pernah berobat ke Poliklinik Penyakit Saraf dan Poliklinik Ilmu Kesehatan Mata tetapi tidak ditemukan kelainan. Dalam keluarga hanya pasien yang mengalami sakit seperti ini. Hal ini sesuai dengan acuan pustaka yang menyatakan adanya tingkat mutasi spontan yang tinggi $65 \% .^{4}$

Epilepsi di jumpai pada 70\% kasus TS. Awitan biasanya fokal yang dimulai sejak lahir tetapi jarang sampai pubertas. Makin dini onset timbulnya kejang, makin besar kemungkinan bayi menderita retardasi mental. Dari sekitar 90\% anak dengan kejang saat usia 1 tahun, hanya $8 \%$ mempunyai IQ rata-rata. ${ }^{11}$ Retardasi mental dijumpai pada $60-70 \%$ kasus TS namun bila perkembangan mental berlangsung normal sejak anak-anak maka jarang dijumpai gangguan mental pada kehidupan lanjut. $^{4}$ Pada pasien ini tidak ditemukan riwayat kejang. Prestasinya di sekolah kurang baik sehingga tidak naik kelas, tidak pernah dibimbing di rumah, dan tes IQ 80 (dibawah rata-rata normal)

Pada gambaran histopatologik ditemukan jaringan kulit dilapisi epidermis dengan hiperkeratosis subepitelial, tampak stroma jaringan ikat fibrokolagen, di antaranya terdapat pembuluh-pembuluh darah kapiler melebar, dan kelenjar-kelenjar sebaseus yang atrofi. Tanda-tanda keganasan tidak ditemukan; hal-hal tersebut sesuai dengan tuberous sklerosis .

Diagnosis banding dengan trikoepi- telioma dapat disingkirkan. Trikoepitelioma mulai timbul pada usia remaja. Lokasi lesi terdapat pada lipatan nasolabial, hidung, dahi, bibir atas, dan kelopak mata, kadang disertai telangiektasis. Gambaran histopatologik yang khas ialah kista tanduk (horn cysts). ${ }^{12,13}$ Diagnosis banding dengan adenoma sebaseus (AS) dapat disingkirkan, karena AS biasanya diderita oleh usia lanjut, serta lokasi lesi biasanya pada wajah, kepala, dan kelopak mata. Gambaran histopatologik berupa tumor berbatas tegas, bentuk tidak teratur, terdiri atas lobulus yang tersusun dari sel-sel kelenjar sebasea dan basaloid. ${ }^{12,14-16}$

Penatalaksanaan pada TS diperlukan multidisiplin ilmu. Umumnya, untuk angiofibroma dapat diterapi dengan eksisi, keratase, penglupasan kulit secara kimia, cryosurgery, dermabrasi, electrosurgery dan laser. Komplikasi yang mungkin dari terapi bedah ialah infeksi, jaringan parut hipertropik, hiperpigmentasi pasca inflamasi, dan hipopigmentasi. ${ }^{1,4,9,17}$ Makula hipomelanotik dapat disamarkan dengan menggunakan lotion atau make up yang sesuai dengan warna kulit. ${ }^{1,4}$

Pilihan terapi baru menggunakan Rapamycin yaitu sejenis antibiotik yang diperoleh dari bakteri Streptomyces hygroscopicus yang juga disebut sirolimus. Obat tersebut merupakan imunosupresan yang digunakan pada organ transplantasi. Cara kerjanya ialah menormalisasikan mammalian target of rapamycin (mTOR) pada jalur rapamycin yang mengalami gangguan dalam sel-sel yang tidak dimiliki baik pada tipe TSC1 maupun TSC2 dan tampaknya merupakan terapi efektif untuk TS. ${ }^{1,3,18,19}$

Percobaan klinis sedang dikembangkan untuk menguji terapi medis yang mungkin untuk tumor TS. Rapamycin oral menyebabkan penurunan astrositomas sel raksasa subependimal, penurunan dalam ukuran ginjal dengan angiomiolipoma (AML), dan memperbaiki fungsi paru pada pasien dengan limfoangioleiomiomatosis (LAM). Beberapa pasien memperlihatkan perbaikan pada angiofibroma dengan terapi rapamycin oral, tetapi efek samping serius 
membatasi penggunaan rapamycin oral, khususya pada anak. Penggunaan topikal dapat menurunkan risiko pemberian sistemik. ${ }^{1,6}$ Terdapat penelitian yang menggunakan Rapamycin topical untuk terapi tuberous sclerosis complex, dengan dosis topikal $0.003-0.015 \%$. $^{1,8,20}$

Pada kasus ini direncanakan untuk elektrokauter tetapi tidak dapat dilanjutkan karena pasien tidak kooperatif. Prognosis pada kasus yang berat meninggal $3 \%$ pada tahun pertama; $28 \%$ pada usia di bawah 10 tahun; dan $75 \%$ pada usia di bawah 25 tahun. Kematian bisa diakibatkan oleh epilepsi atau infeksi berulang, gagal jantung, gagal ginjal, dan fibrosis paru. ${ }^{1,7}$ Prognosis tergantung pada gambaran penyakit. Beberapa individu memeiliki jangka waktu hidup normal dengan sedikit komplikasi medis. ${ }^{1}$ Prognosis pada kasus ini quo ad vitam, quo ad functionam: dubia ad bonam, quo ad sanationam: dubia.

\section{SIMPULAN}

Pada kasus ini diagnosis tuberous sklerosis ditegakkan berdasarkan anamnesis, gambaran klinis, dan pemeriksaan histopatologik. Gambaran klinis berdasarkan 2 kriteria mayor yang ditemukan yaitu angiofibroma pada wajah dan makula hipomelanotik. Tindakan elektrokauter tidak dapat dilakukan karena pasien tidak kooperatif. Prognosis TS tergantung pada gejala klinis, pada pasien qua ad vitam, qua ad functionam: dubia ad bonam, quo ad sanationam: dubia

\section{DAFTAR PUSTAKA}

1. Thomas N, Darling AJ. Tuberous sclerosis complex. In: Goldsmith LA, Katz SI, Gilchrest, Paller AS, Leffell DJ, Woff K, editors. Fitzpatrick's Dermatology in General Medicine (8th ed). New York: McGraw Hill, 2012; p.1671-9.

2. James WD, Berger TG, Elston RM. Tuberous sclerosis. In: Andrew's Diseases of the Skin Clinical Dermatology (11th ed). Philadelphia: Saunders, 2011; p. 542-3.

3. Korf BR. Tuberous sclerosis complex and neurofibrosis. In: Irvine AD, Hoeger PH,
Yan AC, editors. Harper's Textbook of Pediatric Dermatology Vol. 1. Oxford: Wiley-Blackwell, 2011; p. 481-4.

4. Osborn JP, Green AJ. Tuberous Sclerosis. In: Irvine A, Hoeger P, Yan A, editors. Harper's Textbook of Pediatric Dermatology (3rd ed). Oxford: WileyBlackwell, 2011; p.129.1-13.

5. Tsao H, Luo S. Neurofibromatosis and tuberous sclerosis. In: Bolognia JL, Jorizzo JJ, Schaffer JV, editors. Dermatology (3rd ed). New York: Elseiver Saunder, 2012; p. 933-40.

6. Wardhani T. In: Atlas Genodermatoses Indonesia. Jakarta: Kelompok Studi Dermatologis Anak Indonesia, 2013; p. 125-7.

7. Schwartz RA. Genetics of tuberous sclerosis. Available from: http: //www.emedicine.medscape.com/ last update March 27, 2015.

8. Koenig MK, Hebert AA, Roberson J, Samuels J, Slopis J, Woerner A, et al. Topical Rapamycin Therapy to Alleviate the Cutaneous Manifestations of Tuberous Sclerosis Complex A doubleblind, randomized, controlled trial to evaluate the safety and efficacy of topically applied rapamycin. Drugs RD. 2012;129(3):121-6.

9. Habif P. Tuberous Sclerosis. In: Clinical Dermatology A Colour Guide to Diagnosis Therapy (5th ed). Oxford: Mosby, 2004; p. 909-12.

10. Koenig MK, Northrup H. The Development of a topical therapy for facial angiofibromas in TSC. Bench to bedside medicine. Houston: Department of Pediatrics The University of Texas Medical School. Available from: http://www.tsalliance.org.2011.

11. Nambi R, Sahn EE. Dermatologic manifestations of tuberous sclerosis. Available from: http:// www.emedicine.com. Aug 1, 2014.

12. Calonje E. Tumor of the skin. In: Burn T, Breathnach S, Cox N, Griffith C, editors. Rook Text Book of Dermatology Vol 1 (8th ed). Online ISBN: 9781444317633. Oxford: Willey-Blackwell, 2010; p. 53.1.

13. Rapini RP. Follicular neoplasms. In: Practical Dermatopathology (2nd ed). Houston: Elsevier Saunders, 2012; p. 315. 
14. Rapini RP. Sebacceous neoplasms. In: Practical Dermatopathology (2nd ed). Houston: Elsevier Saunders, 2012; p. 307.

15. Vibriyanti R, Silayukti KA, Iga SP, Adiguna S. Tuberous Sclerosis kompleks pada remaja dan balita. Denpasar: FK Universitas Udayana, RSUP Sanglah Denpasar.

16. Rapini RP. Fibrohistiocytic proliferations and neoplasms. In: Practical Dermatopathology (2nd ed). Houston: Elsevier Saunders, 2012; p. 383-5.

17. Lawrence FE, Illona JF, Eichenfield, Esterbg. Tuberous Sclerosis Complex. In: Neonatal and Infant Dermatology (2nd ed). San Diego: Elsevier Saunders,
2008; p. 387-9.

18. Irvine AD, Mellerio JE. In: Burn T, Breathnach S, Cox N, Griffith C, editors. Rook's Text book of Dermatology Vol 1 (8th ed). Online ISBN: 9781444317633. Oxford: Wiley-Blackwell, 2010; p. 15. 20-24.

19. Schwartz RA. Tuberous Sclerosis complex; advance in diagnosis, genetics and management. Journal of America Academy of Dermatology. 2007;57:189202.

20. Tuberous sclerosis. [cited 2014 Sept 5]. Available from: http://wikipedia.org/wiki/tuberousscleros is 